\title{
Association of giant congenital melanocytic nevus, halo nevus and vitiligo in a 75-year-old patient
}

\author{
Associação de nevo melanocítico congênito gigante, nevo halo e vitiligo. \\ Relato de caso em paciente de 75 anos
}

\author{
Marina Leite da Silveira ${ }^{1}$ \\ Marcia Lanzoni Alvarenga ${ }^{3}$
}

\author{
Flávia Regina Ferreira ${ }^{2}$ \\ Samuel Henrique Mandelbaum ${ }^{4}$
}

\begin{abstract}
A giant congenital melanocytic nevus represents a rare condition. The halo phenomenon may be seen in congenital or acquired melanocytic nevi. In the literature, association of halo nevus and giant congenital melanocytic nevus is rare and the association of both with vitiligo even more rare. A 75-yearold woman at first consultation complained of a hyperchromic bluish-brown hairy macula on the lower back, buttocks and thighs present since birth and an achromic halo of onset three years ago. The histological features were consistent with congenital melanocytic nevus and halo nevus, respectively. After two years the patient developed achromic areas in normal skin, histologically consistent with vitiligo. The authors emphasize the rarity of this triple combination, the patient's age and the absence of malignant degeneration to date.
\end{abstract}

Keywords: Nevus, halo; Nevus, pigmented; Vitiligo

\begin{abstract}
Resumo: Nevo melanocitico congênito gigante constitui uma condição rara. O fenômeno halo pode ser observado em nevos melanocíticos congênitos ou adquiridos. Na literatura a associação nevo halo e nevo melanocítico congênito gigante é rara e a associação de ambos com vitiligo ainda mais rara. Mulher de 75 anos que à primeira consulta apresentava mácula hipercrômica castanho-azulada pilosa na região lombar, nádegas e coxas desde o nascimento e halo acrômico de aparecimento há 3 anos. Os histológicos foram compatíveis com nevo melanocítico congênito e nevo halo respectivamente. Após dois anos evoluiu com áreas de acromia à distância, com histológico de vitiligo. Os autores ressaltam a raridade desta tripla associação; a idade da paciente e a ausência de degeneração maligna até o presente momento.

Palavras-chave: Nevo com halo; Nevo pigmentado; Vitiligo
\end{abstract}

Received on 29.03.2011.

Approved by the Advisory Board and accepted for publication on 20.06.2011.

* Study carried out at the Teaching Hospital of Taubaté, University of Taubaté (Hospital Universitário de Taubaté - Universidade de Taubaté - HU-UNITAU) Taubaté (SP), Brazil.

Conflict of interest: None

Financial funding: None

Physician - Intern at the Dermatology Service, Teaching Hospital of Taubaté, University of Taubaté (Hospital Universitário de Taubaté - Universidade de Taubaté - HU-UNITAU) - Taubaté (SP), Brazil.

Master's degree in Science by the Paulista Medical School - Federal University of São Paulo (Escola Paulista de Medicina - Universidade Federal de São Paulo - (EPM-UNIFESP) - Assistant Professor III, Discipline of Dermatology, Department of Medicine, University of Taubaté (UNITAU) - Dermatologist of the Dermatology Service, Teaching Hospital of Taubaté, University of Taubaté (Hospital Universitário de Taubaté - Universidade de Taubaté - HU-UNITAU) - Taubaté (SP), Brazil.

Specialist - Assistant Professor I, Discipline of Special Pathology, Department of Medicine, University of Taubaté (UNITAU) - Pathologist of the Dermatology Service, Teaching Hospital of Taubaté, University of Taubaté (Hospital Universitário de Taubaté - Universidade de Taubaté - HU-UNITAU) - Taubaté (SP), Brazil. Specialist - Assistant Professor I, Discipline of Dermatology, Department of Medicine, University of Taubaté (UNITAU) - Head of the Dermatology Service, Teaching Hospital of Taubaté, University of Taubaté (Hospital Universitário de Taubaté - Universidade de Taubaté - HU-UNITAU) - Taubaté (SP), Brazil. 


\section{INTRODUCTION}

Congenital melanocytic nevi (CMN) are present in approximately one per cent of newborns and may be classified according to their size into small $(<1.5 \mathrm{~cm})$, medium-sized $(1.5-10 \mathrm{~cm})$, relatively common, large $(11-20 \mathrm{~cm})$ and giant $\mathrm{CMN}(>20 \mathrm{~cm})$. The latter is a more rare condition, with an estimated incidence of one in every 20 thousand births. ${ }^{1,2,3}$

The halo nevus or leukoderma aquisitum centrifugum was first described by Sutton in 1916, and is also known as Sutton nevus. It may be observed around congenital or acquired melanocytic nevi, being more rare in congenital nevi. ${ }^{4}$

In two large studies, association of halo nevus and vitiligo was observed in $7.2 \%$ and $4.4 \%$ of the patients. ${ }^{5,6,7}$

Until this moment, reports of halo nevus in giant CMN are scarce in literature and the association halo nevus, giant CMN and vitiligo is even more rare. ${ }^{8}$

\section{CASE REPORT}

A female patient, currently 75-years-old, of mixed race, homemaker, born in and from Taubaté (SP) complained of a "macula on her back since birth that is disappearing" and informed she had looked for the Dermatology Service for the first time 13 years ago. On this occasion she presented hyperchromic bluish-brown hairy macula that extended over the lumbar region, buttocks and thighs, surrounded by achromic halo that had its onset three years ago (Figure 1). Two biopsies were carried out: one in the hyperchromic and another in the achromic areas. The histopathological examination of the first sample revealed skin with diffuse melanosis of basal layer

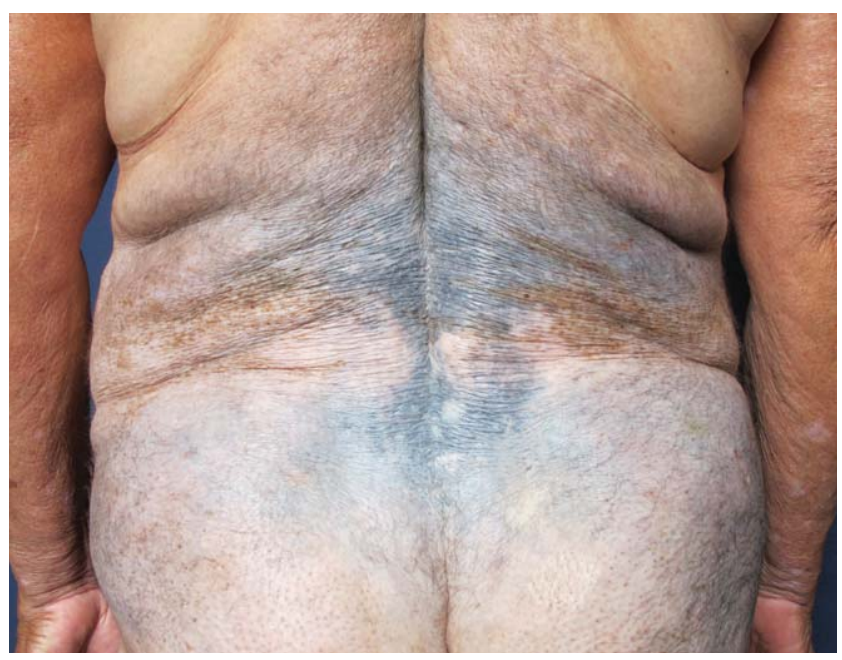

FIGURE 1: Hyperchromic bluish-brown hairy macula extending over the lumbar region, buttocks and thighs, interspersed with achromic areas

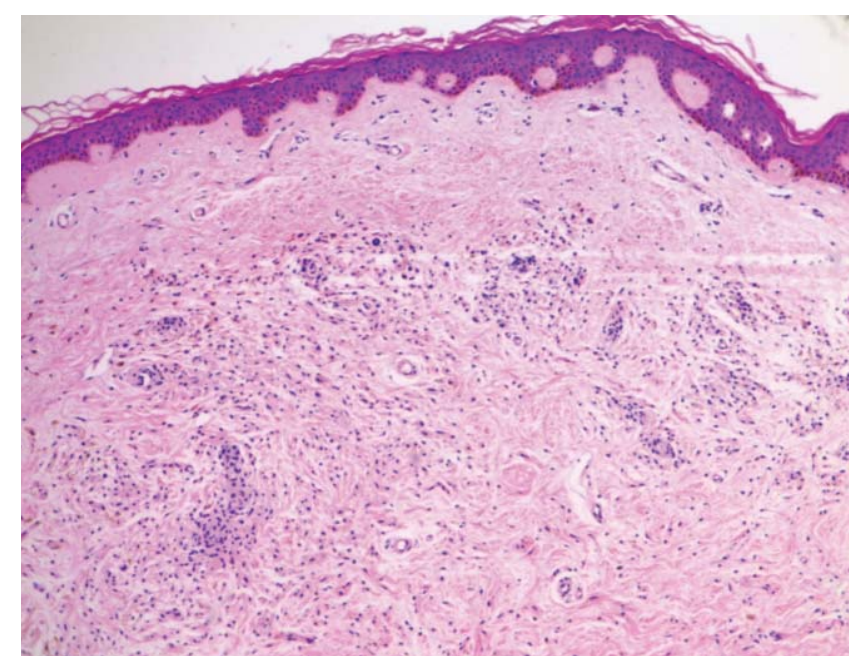

Figure 2: M Diffuse melanosis of basal layer and typical, fusiform, pigmented melanocytic proliferation in the deep dermis, compatible with congenital melanocytic nevus. (HE 100x)

beside typical, fusiform, pigmented melanocytic proliferation in the deep dermis compatible with congenital melanocytic nevus (Figure 2). The second sample presented absence of melanic pigment in the basal layer, hyalinization of superficial dermis and subjacent nevus, compatible with nevus in remission (halo nevus) (Figure 3). After two years of follow-up, the patient progressed with achromic areas around other nevi (acquired) and in healthy skin areas, non related to previous nevic lesions (Figures 4 and 5). The histopathological examination of the skin in the abdominal region showed new evidence of epidermis with total absence of melanine in its basal layer and absence of

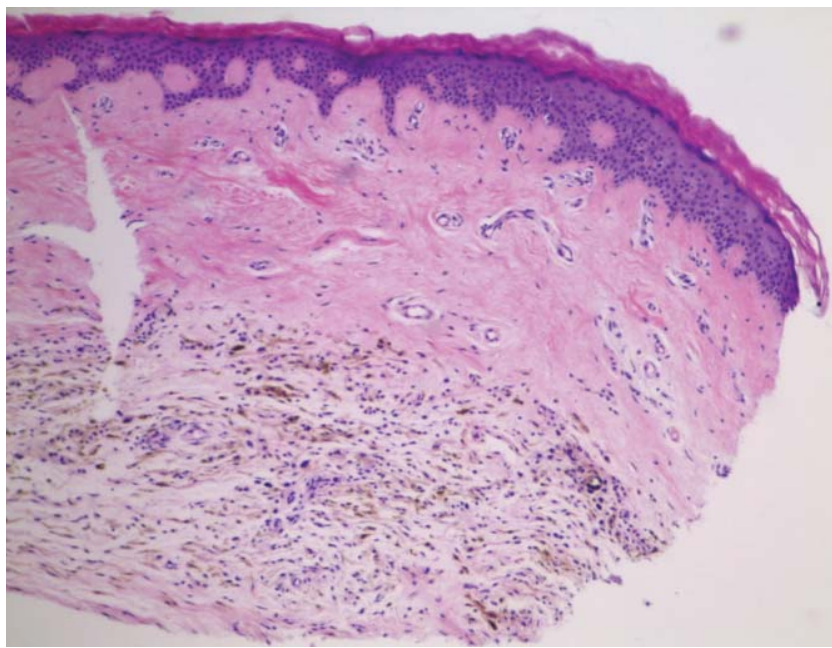

FIGURE 3: Absence of melanic pigment in the basal layer, hyalinization of superficial dermis and subjacent nevus, compatible with nevus undergoing regression (halo nevus) (HE 100x) 


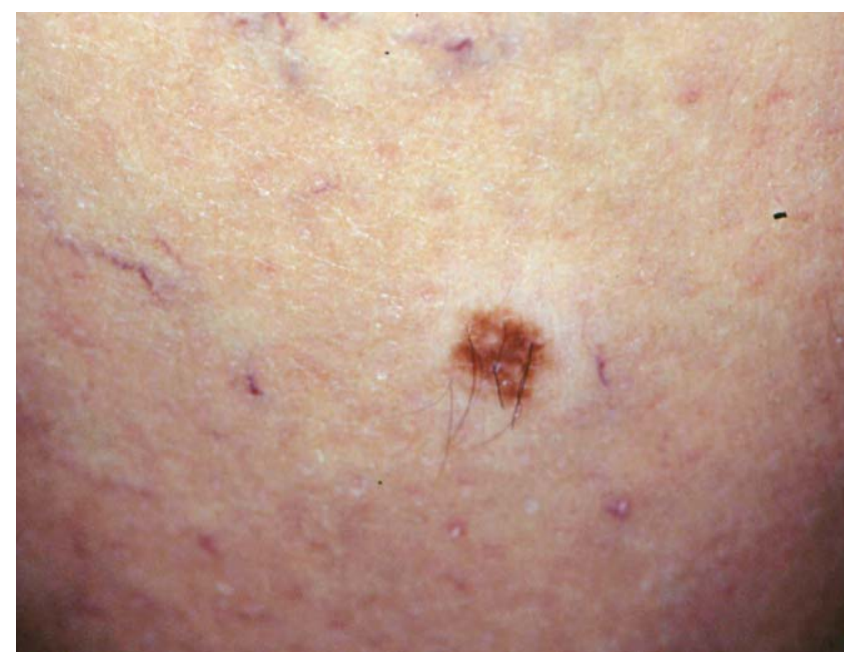

Figure 4: Halo nevus around acquired nevus on thigh

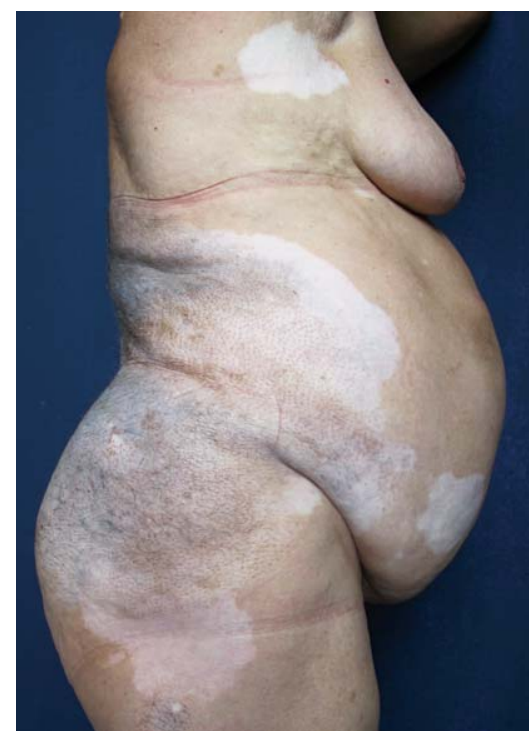

Figure 5: Perilesional (perinevic) achromic halo and extralesional vitiligo areas melanocytes, compatible with the vitiligo clinical picture (extralesional vitiligo) (Figure 6). The patient has been monitored for 13 years, both clinically and histologically, without any evidence of malignant degeneration of the giant congenital melanocytic nevus, which has been gradually lightening and disappearing; the dermal component of the nevus (gray-bluish aspect) is the most apparent today. During this entire period, several treatments were tried in an attempt to stabilize the condition and achieve repigmentation of vitiligo patches with systemic and topical corticotherapy: oral psoralen with sunlight exposure, vitamins (folic acid, vitamin C) and tacrolimus, with discrete results. During follow-up, the patient also developed diabetes mellitus and hypothyroidism, controlled with the use of insulin, metformin and levothyroxine.

\section{DISCUSSION}

The present report describes a rare case of association of giant congenital melanocytic nevus, halo nevus and vitiligo.

The progression of congenital melanocytic nevi $(\mathrm{CMN})$ is very varied. They may remain unaltered during the entire live of the patient, undergo malignant degeneration, present color alterations (lightening or darkening) or developing achromic perilesional halos with consequent involution of the nevus (halo nevus), as described in this case.'

The risk for small and medium-sized CMN malignization is low, and for large and giant CMN it varies from 1 to $42 \%$. This risk is higher before puberty in giant $\mathrm{CMN}$, while it is higher after puberty in small and medium-sized nevi. ${ }^{10}$

The halo nevus, leukoderma aquisitum centrifugum or Sutton nevus (1916) occurs in approximate- ly $1 \%$ of all the Caucasian adult population, ${ }^{4,11,12}$ mainly on the upper part of the body. ${ }^{4}$ Its prevalence among other ethnic groups has not been reported in the literature. ${ }^{11}$ The halo phenomenon may be observed around congenital or acquired melanocytic nevi, nevocellular nevus, blue nevus, Spitz nevus, neurofibromas and primary or metastatic melanomas. ${ }^{10,11}$

The onset of vitiligo is usually in childhood or young adults, and only rarely it appears late as presented in this report. Approximately half of vitiligo cases occur before 20 years of age. ${ }^{13}$

The halo nevus is frequently associated with vitiligo; between $20 \%$ and $50 \%$ of vitiligo patients also have halo nevus. Although the pathogenesis of halo

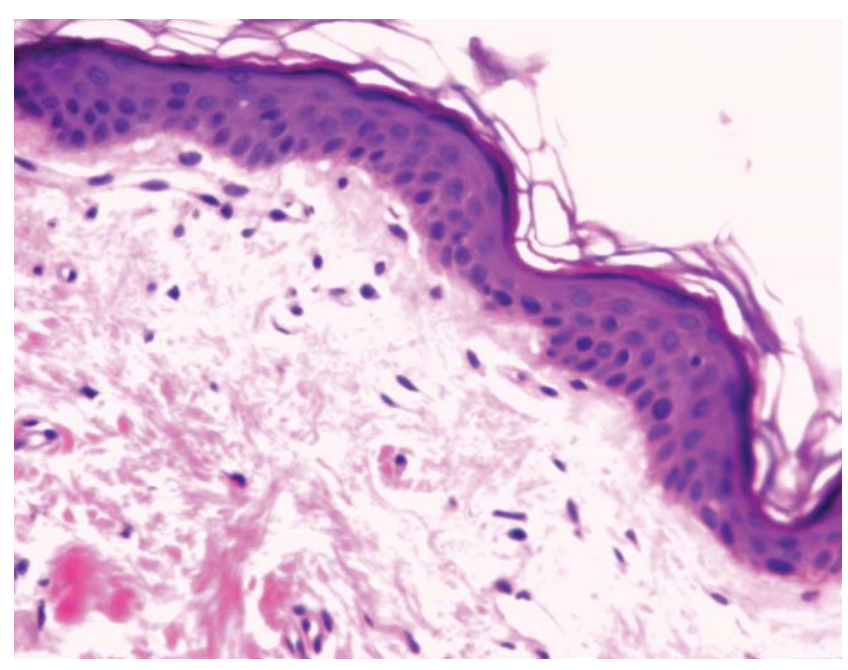

FIGURE 6: Epidermis total absence of melanin in its basal layer and absence of melanocytes, compatible with vitiligo (HE 400x) 
and vitiligo formation are not clearly understood, several theories suggest that both phenomena result from an immunological response to the pigmented cells present both in normal skin and within the nevic lesion. ${ }^{8}$

Vijlder and cols. investigated associations of human leukocytary antigens (HLA) class II of two subtypes of vitiligo: vitiligo vulgaris and vitiligo associated with halo nevus and revealed different types of HLA class II among the studied subtypes, suggesting distinct pathogeneses. In vitiligo vulgaris the autoimmune reaction is directed against antigens originated in normal melanocytes. In vitiligo associated with halo nevus the autoimmune reaction is also against normal melanocytes, but preceded by autoimmune reaction against antigens originated in nevic melanocytes. This study also demonstrated a mean age for the onset of halo nevus as 32 years, varying from 13 to 65 years. ${ }^{14}$

The authors emphasize the rarity of this triple association in the literature, with only one case described in a Japanese 49-year-old patient. ${ }^{8}$ In addition, the exuberance of the case, the advanced age of the patient and the absence of malignant degeneration up to the moment justify this report.

\section{REFERENCES}

1. Paschoal FM. Nevo melanocítico congênito. An Bras Dermatol. 2002;77:649-56.

2. Zack LD, Stegmeier 0, Lawrence MS. Pigmentary Regression in a giant nevocelluIar nevus: a case report and a review of the subject. Pediatr Dermatol. 1988;5:17883.

3. Chung C, Forte AJV, Narayan D, Persing J. Giant nevi: a review. J Craniofac Surg. 2006;17:1210-5.

4. Hofmann UB, Bröcker EB, Hamm H. Simultaneous onset of segmental vitiligo and a halo surrounding a congenital melanocytic naevus. Acta Derm Venereol. 2009;89:402-6.

5. Hu Z, Liu JB, Ma SS, Yang S, Zhang XJ. Profile of childhood vitiligo in China: an analysis of 541 patients. Pediatr Dermatol. 2006;23:114-6.

6. Schallreuter KU, Lemke R, Brandt O, Schwartz R, Whesthofen M, Montz R, et al. Vitiligo and other diseases: coexistence or true association? Hamburg study on 321 patients. Dermatology. 1994;188:269-75.

7. Handa S, Dogra S. Epidemiology of childhood vitiligo: a study of 625 patients from north India. Pediatr Dermatol. 2003;20:207-10.

8. Stierman SC, Tierney EP, Shwayder TA. Halo congenital nevocellular nevi associated with extralesional vitiligo: a case series with review of the literature. Pediatric Dermatol. 2009;26:414-24

9. Shin JH, Kim MJ, Cho S, Whang KK, Hahm JH. A case of giant congenital nevocytic nevus with neurotization and onset of vitiligo $\mathrm{J}$ Eur Acad Dermatol Venereol. 2002;16:384-6

10. Fernandes NC, Machado JLR. Estudo clínico dos nevos melanocíticos congênitos na criança e no adolescente. An Bras Dermatol. 2009;84:129-35.
11. Leow JL, Goh BK. Halo congenital naevus in a middle-aged patient with vitiligo. Australas J Dermatol. 2008;49:229-32.

12. Itin $\mathrm{PH}$, Lautenschlanger $\mathrm{S}$. Acquired leukoderma in congenital pigmented nevus associated with vitiligo-like depigmentation. Pediatr Dermatol. 2002;19:73-5.

13. Dogra S, Parsad D, Handa S, Jit Kanwar A. Late onset vitiligo: A study of 182 patients. Int J Dermatol. 2005;44:193-6.

14. de Vijlder HC, Westerhof W, Schreuder GM, de Lange P, Claas FH. Difference in pathogenesis between vitiligo vulgaris and halo nevi associated with vitiligo is supported by an HLA association study. Pigment Cell Res. 2004;17:270-4.

\author{
MAILING ADDRESS: \\ Flávia Regina Ferreira \\ Avenida Granadeiro Guimarães, 270 - Centro \\ 12020-130 Taubaté, SP \\ E-mail: dermagica@uol.com.br
}

How to cite this article: Silveira ML, Ferreira FR, Alvarenga ML, Mandelbaum SH. Association of giant congenital melanocytic nevus, halo nevus and vitiligo in a 75-year-old patient. An Bras Dermatol. 2012;87(2):288-91. 